\title{
Temperature Effect on HFMD Transmission in Selangor, Malaysia
}

\author{
(Kesan Suhu kepada Penularan HFMD di Selangor, Malaysia)
}

\author{
Nurmarni Athirah Abdul Wahid, Jamaludin Suhaila* \& Ayuna SuleKan
}

\begin{abstract}
Hand, foot, and mouth disease (HFMD) has become a major concern for health authorities all over the world including Malaysia. In Malaysia, it has been reported that more than fifteen thousand people were affected by this disease in the year 2016 and it is suspected that climate variables play an important role in the incidence of HFMD. Previous studies showed that HFMD disease is associated with climatic factors such as temperature, humidity, and rainfall. Hence, this paper attempts to examine the pattern of HFMD and scrutinize the effect of temperature on HFMD in Selangor from the year 2010 to 2016. Correlation analysis is conducted to measure the relationship between HFMD incidence and temperature with a lag time effect. The generalized linear model (GLM) is then carried out to determine the influence of climate variables on HFMD disease in Selangor. Our findings discovered that the weekly mean temperature is significantly associated with HFMD incidence in Selangor. A comparison between models shows that HFMD with 2 weeks lag time mean temperature is the best-fitted model of HFMD in Selangor. This result helps to lay sound evidence for the implementation of strategies to reduce the effect of climate change especially temperature towards HFMD.
\end{abstract}

Keywords: Climate change; disease; generalized linear model; HFMD; temperature

\section{ABSTRAK}

Penyakit tangan, kaki dan mulut (HFMD) telah menjadi kebimbangan utama bagi pihak berkuasa kesihatan di seluruh dunia termasuk Malaysia. Di Malaysia, lebih daripada lima belas ribu orang telah dilaporkan terjejas kerana dijangkiti oleh penyakit ini pada tahun 2016 dan disyaki bahawa perubahan iklim memainkan peranan yang penting terhadap penyakit HFMD. Kajian terdahulu menunjukkan bahawa penyakit HFMD dikaitkan dengan faktor iklim seperti suhu, kelembapan dan hujan. Oleh itu, kertas ini bertujuan untuk mengkaji corak HFMD dan mengenal pasti kesan suhu terhadap penyakit HFMD di negeri Selangor bermula dari tahun 2010 sehingga 2016. Analisis korelasi dilakukan terlebih dahulu untuk mengukur hubungan antara penyakit HFMD dan suhu yang dipengaruhi oleh kesan sela masa. Model linear teritlak kemudian dilakukan untuk menentukan pengaruh perubahan iklim terhadap penyakit HFMD di Selangor. Hasil kajian kami melalui perbandingan antara model menunjukkan bahawa penyakit HFMD dengan sela masa suhu sebanyak dua minggu merupakan model yang terbaik bagi HFMD di Selangor. Hasil daripada kajian ini dapat membantu bagi pelaksanaan strategi untuk mengurangkan kesan perubahan iklim seperti suhu terhadap penyakit HFMD

Kata kunci: HFMD; model linear teritlak; penyakit; perubahan iklim; suhu

\section{INTRODUCTION}

Recently, the cases of hand, foot, and mouth disease (HFMD) has rapidly increased in many countries. HFMD is defined as a common disease that usually affects children below the age of five. It is characterized by rapidly ulcerating vesicles in mouth and lesions, usually vesicular on the hand and feet (Melnick 1984). HFMD disease is caused by Enterovirus with a majority of cases caused by Coxsackie Virus A16 and Enterovirus 71 (EV71). The virus spreads in contact with saliva, blister fluid and patient stool. Infection habits are mild with symptoms of fever followed by blisters on the hands, feet, mouth, and tongue (Ministry of Health Malaysia 2012). These symptoms will show up after three to seven days of infection. A person will begin with a mild fever, poor appetite, malaise or feeling unwell and often sore throat (Centers for Disease Control and Prevention 2011).

HFMD patients caused by Enterovirus 71 (EV71) are more linked with severe symptoms including the central nervous system disorders and fatality resulting 
from pulmonary edema in a small proportion of children, especially those children aged under 5 years old, while, HFMD patients who have been infected by the Coxsackie A16 virus can usually recover within 7 to 10 days (Cohen 1998). In 1957, HFMD disease was first introduced clinically in Canada and New Zealand. Thomas Henry Flewett called the disease 'Hand, Foot and Mouth Disease' after a similar outbreak of this disease in the year 1960 (Alsop et al. 1960). HFMD is now considered an emerging infectious disease that affects the population worldwide and this is due to the global population growth, frequent international traveling, urbanization, and crowded habitats.

This disease may occur in a cluster or outbreak that may lead to death if there is any complication developed. An outbreak of HFMD disease has occurred in many areas such as China, Japan, Hong Kong, the Republic of Korea, Malaysia, Singapore, Thailand, Taiwan, Vietnam, the United States of America, Europe, Brazil, and many more countries. In 1997, there was an outbreak reported which mostly in East and South East Asia, primarily affecting children (Koh et al. 2016). Asian countries have experienced an increasing trend of HFMD outbreaks in the past decades, resulting thousands of deaths among children due to severe complications (Xing et al. 2014).

In Malaysia, HFMD contagious disease has become an endemic causing outbreak among children even though Malaysia has some of the best health care systems and technologies available. A widespread community outbreak of HFMD, primarily caused by EV71 infection, began in Sarawak early in April 1997. Sarawak State Department of Health reported that there were 2628 total cases of this disease from 1 June to 30 August 1997. During the outbreak, 889 children were hospitalized, including 39 patients with aseptic meningitis or acute flaccid paralysis. A total of 29 previously healthy children younger than six years of age died of rapidly progressive cardiorespiratory failure and EV71 was isolated in samples from six of the fatal cases (Chan et al. 2000).

HFMD disease was then spread in Peninsular Malaysia in June 1997 with an outbreak involving 4625 hospital admissions, resulting in 11 fatal cases (Shekhar et al. 2005). A sentinel surveillance program for HFMD was subsequently established in Sarawak in March 1998. Between March 1998 and June 2005, 4290 specimens were collected from 2950 children, with a male-to-female ratio of 1.4:1. During that period, two large outbreaks were identified in Sarawak, in the years 2000 and 2003. EV71 was the dominant Enterovirus serotype of the isolates in both years (Podin et al. 2006). Next, in 2007, an outbreak of HFMD was only detected in Peninsular Malaysia. The outbreak was reported almost purely due to CA16 through EV71 isolated from 18 out of 5380 patients in clinical samples study (Chua \& Kasri 2011).
In recent years, there has been an increasing amount of literature on the effects of climatic factors towards HFMD such as in Hong Kong, Singapore, Japan, China, Taiwan, and South Korea. They showed that HFMD incidence is strongly associated with climatic factors (Hii et al. 2011; Hu et al. 2012; Kim et al. 2016; Lee et al. 2015; Ma et al. 2010; Onozuka \& Hashizume 2011). For example, a study in China used the method of the generalized linear model and reported that climatic factors such as temperature has a positive impact on HFMD (Gou et al. 2018). Besides, by using the generalized additive model technique, a study in South Korea indicated that the number of HFMD cases in South Korea increased significantly with the increase in average temperature and relative humidity (Kim et al. 2016). Another study in Hong Kong showed that wind speed and rainfall showed a positive association with HFMD disease in their country (Wang et al. 2016). Some studies stated that HFMD disease has clear seasonality (Hii et al. 2011; Li et al. 2014; Van et al. 2007).

However, the study related to the effect of climate change on HFMD is still limited in Malaysia. The most popular study that commonly conducted by the researcher related to climate change is dengue cases (Fairos et al. 2010; Husam et al. 2017; Rasidi et al. 2013). As such, this study is aimed to examine the pattern of HFMD occurrence and the effect of temperature on HFMD incidence in Selangor from the year 2010 to 2016. Besides, this study will also identify the lag periods of the explanatory variable that have a significant effect on the HFMD incidence. The preliminary study only focuses on the state of Selangor. The findings in this study can provide the information that may be useful for a better understanding of epidemic trends of HFMD disease in Selangor and thus can help to develop an early warning system. Besides, this study may also increase the level of awareness towards HFMD disease and hence, Malaysia can take precaution measure for this disease related to climate factors to prevent it from spreading.

\section{MATERIALS AND METHODS}

\section{STUDY AREA}

This study covered the state of Selangor, Malaysia located on the west coast of the Peninsular Malaysia $\left(3^{\circ} 20^{\prime} \mathrm{N}\right.$ $101^{\circ} 30^{\prime} \mathrm{E}$ ) occupying a land space of $8,104 \mathrm{~km}^{2}$. As of the 2018 census, the state's population is $6,448,400$. Selangor has a tropical rainforest climate bordering on tropical monsoon climate. There are nine main districts in Selangor, mainly Gombak, Hulu Selangor, Hulu Langat, Klang, Kuala Langat, Kuala Selangor, Petaling, Sabak Bernam and Sepang. The geographical location of the study area is shown in Figure 1. 


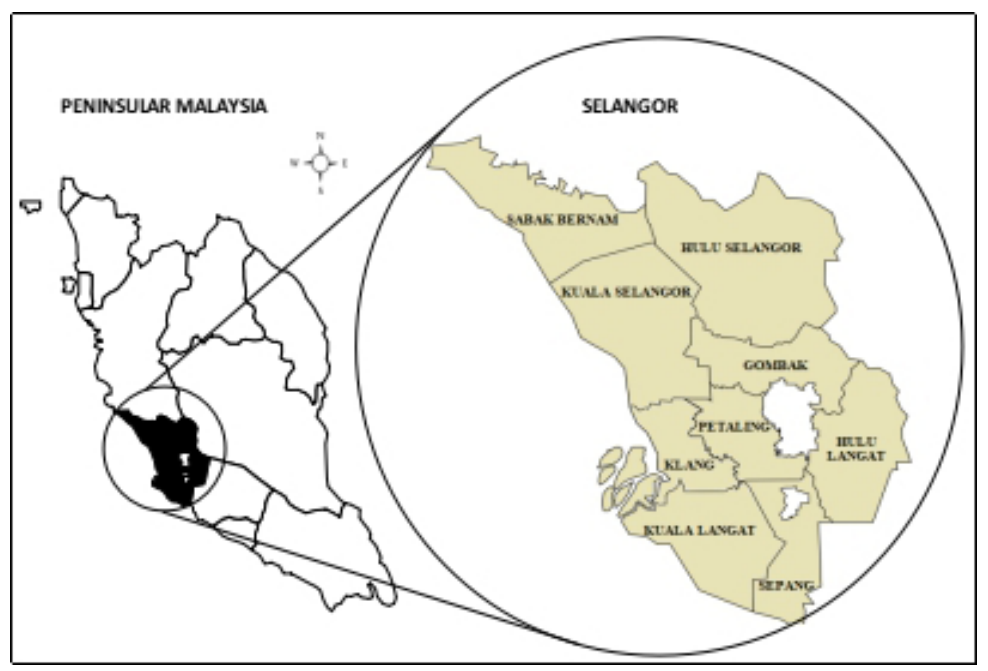

FIGURE 1. Location of Selangor, Malaysia

\section{SURVEILLANCE DATA}

Data on weekly reported HFMD cases in Selangor, Malaysia from the year of 2010 to 2016 were obtained from the Ministry of Health, Malaysia. The dataset consists of gender, age, ethnic, and HFMD cases on weekly basis in Selangor. The HFMD cases were diagnosed with one or more signs such as fever, ulcers in the mouth, rash or blisters on the palms and toes (Ministry of Health Malaysia 2012).

\section{METEOROLOGICAL DATA}

Data on weekly temperature was obtained from the Malaysian Meteorological Department for Subang stations in Selangor from the year of 2010 to 2016. The Malaysian Meteorological Department (MetMalaysia) is an agency under the Ministry of Energy and Climate Change (MESTEC) which is responsible for providing various meteorological, climate and geophysical services to meet the needs of the nation for well-being, safety, and sustainable development.

\section{STATISTICAL METHODS}

\section{DESCRIPTIVE STATISTICS}

As a preliminary analysis, descriptive statistics were performed to examine the pattern of HFMD disease in Selangor from the year of 2010 to 2016. The response variable used in this study is the number of HFMD cases per week and the explanatory variable is the temperature measured in Celsius. Spearman's correlation analysis was used to identify the association between HFMD incidence and temperature.

\section{REGRESSION MODELS}

A generalized linear model (GLM) with the Poisson family was then used to develop a model for HFMD incidence in Selangor. Poisson distribution appears to be appropriate when the response variable consists of non-negative integers and not normally distributed (Kleinbaum et al. 1988). Besides, the Poisson distribution is available for modeling variables that describe count or discrete data of the occurrences of some event over a specified interval in which this is the common process in clinical and epidemiological research (Parodi \& Bottarelli 2006; Pedan 2001). The Poisson regression analysis assumes that the distribution of response variable $Y$ is under consideration of the Poisson family. The family of Poisson distribution with parameter $\mu$ is given by formula as follows:

$$
P\left(Y=y_{i}\right)=\frac{e^{-\mu_{i}} \mu_{i}^{y_{i}}}{y_{i}}, y_{i}=0,1,2,3, \ldots, \infty, i=1,2,3, \ldots, p
$$

where $Y$ is a random variable representing the number of HFMD cases at week $i$ for a given period $p, \mu_{i}$ is both mean and variance of $Y$. To develop the HFMD model, $\mu_{i}$ is expressed as a function of some explanatory variable through a log link function. The logarithm of the response variable is linked to a linear function of the explanatory variable as the following form:

$$
\ln (Y)=\beta_{0}+\beta_{1} X_{1}+\ldots+\beta_{k} X_{k}
$$

and

$$
Y=\exp \left[\beta_{0}+\beta_{1} X_{1}+\ldots+\beta_{k} X_{k}\right]
$$


On the other hand, the change in climate condition will affect the HFMD activity, thus, the delayed effects of climatic factors should be considered, taking into account the incubation period of HFMD. In this study, we assumed that the incubation period for HFMD was about 1 to 3 weeks, similar to the study done in Hong Kong (Ma et al. 2010). We examined the effect of temperature using different lag time, 1, 2, and 3 weeks. For example, lag 0 corresponds to the current week for both HFMD cases and temperature, whereas lag 1 corresponds to the current week for HFMD cases and previous week of temperature. The Poisson regression model with a lag effect is written in the following form:

$$
\ln (\text { HFMD_cases })=\beta_{0}+\beta_{1}(\text { Temperature })_{t-i}
$$

where $\beta_{0}$ is constant, $\beta_{1}$ is the unknown parameter values to be estimated and $i$ is a finite distributed lag operator, for example, $i=1$ means distributed lag 1 week.

In modeling the Poisson regression model, the equality of the mean and variance is considered, otherwise, an overdispersion can arise. Overdispersion means that the observed variance is larger than the assumed variance. Thus, Breslow (1984) suggested the negative binomial regression model can be used to overcome the overdispersion issues. The negative binomial distribution is a form of the Poisson distribution in which the distribution's parameter itself is considered a random variable. Under the Poisson distribution, the mean $\lambda_{i}$ is assumed to be constant within the classes. Yet, the heterogeneity within the classes is not allowed by defining a specific distribution for $\lambda_{i}$. By assuming $\lambda_{i}$ to be a gamma distribution with the mean $E\left(\lambda_{i}\right)=\mu_{i}$ and variance $\operatorname{Var}\left(\lambda_{i}\right)=\mu_{i}^{2} v_{i}^{-1}$, and $Y_{i} \mid \lambda_{i}$ to be a Poisson with conditional mean $E\left(Y_{i} \mid \lambda_{i}\right)=\lambda_{i}$, therefore, it can be shown that the marginal distribution of $Y_{i}$ follows a negative binomial distribution with the probability function as follows:

$$
\begin{gathered}
\operatorname{Pr}\left(Y_{i} \mid y_{i}\right)=\int \operatorname{Pr}\left(Y_{i}=y_{i} \mid \lambda_{i}\right) f\left(\lambda_{i}\right) d \lambda_{i}= \\
\frac{\Gamma\left(y_{i}+v_{i}\right)}{\Gamma\left(y_{i}+1\right) \Gamma\left(v_{i}\right)}\left(\frac{v_{i}}{v_{i}+\mu_{i}}\right)^{v_{i}}\left(\frac{\mu_{i}}{v_{i}+\mu_{i}}\right)^{y_{i}}
\end{gathered}
$$

where the mean and variance are $E\left(Y_{i}\right)=\mu_{i}$ and $\operatorname{Var}\left(Y_{i}\right)=\mu_{i}+\mu_{i}^{2} v_{i}^{-1}$, respectively.

\section{EVALUATING OF THE BEST MODEL}

In this study, Akaike information criterion (AIC) and deviance statistic methods are used for both Poisson and negative binomial models to find the goodness of the fitted model. AIC estimates the quality of the model and hence, it provides a mean of model selection. It is also the best method that can be used to determine the most appropriate estimated model of the data (Akaike 1998). The lowest value of AIC indicates the best performance of the estimated models. The formula of AIC is expressed as follows:

$$
A I C=2 k-2 \ln (\hat{L})
$$

where $k$ is the number of estimated parameters in the model and $\hat{L}$ is the maximum value of the likelihood function for the model.

Besides, the deviance statistics method is also used as a measurement in the goodness of fit model for both Poisson and negative binomial models. Deviance is defined as twice the difference between the maximum likelihood achievable and the likelihood of the fitted model. The scale deviance denoted as below:

$$
D(\beta)=2\left\{l_{\max }-l(\beta)\right\} \phi
$$

where $l$ is the log-likelihood of the model; and $l_{\max }$ is the maximum possible values for $l$ given the observed data obtained by considering the maximum likelihood estimation (MLE) of a model with one parameter per datum under which the model predicted $E\left(y_{i}\right)$ is simply $y_{i .} \phi$ is a scale parameter and D means that it can be calculated without knowledge of $\phi$ (Wood 2008). All the analyses were conducted using $\mathrm{R}$ programming statistical software. The estimated parameters that have a $p$-value $<0.05$ were considered as statistically significant.

\section{RESULTS AND DISCUSSION}

\section{THE PATTERN OF HFMD IN SELANGOR}

The number of HFMD cases in Selangor, Malaysia from the year of 2010 to 2016 is shown in Figure 2. The incidence of this disease shows a fluctuated pattern over these years. In the year 2010, the number of reported HFMD cases was 1853 . However, more than 2000 cases have been reported every year from 2012 to 2016 . Besides, a decrease in the number of reported HFMD cases has been notified, decreasing from 1853 to 1208 cases in the year of 2011. Selangor experienced the greatest burden of the disease in the year of 2016 with 15074 cases followed by the year of 2014 and 2012 with 9121 and 6571 cases, respectively. The incidence of HFMD cases in Selangor increased rapidly in the year of 2015 to 2016 from 4759 to 15074 cases. 


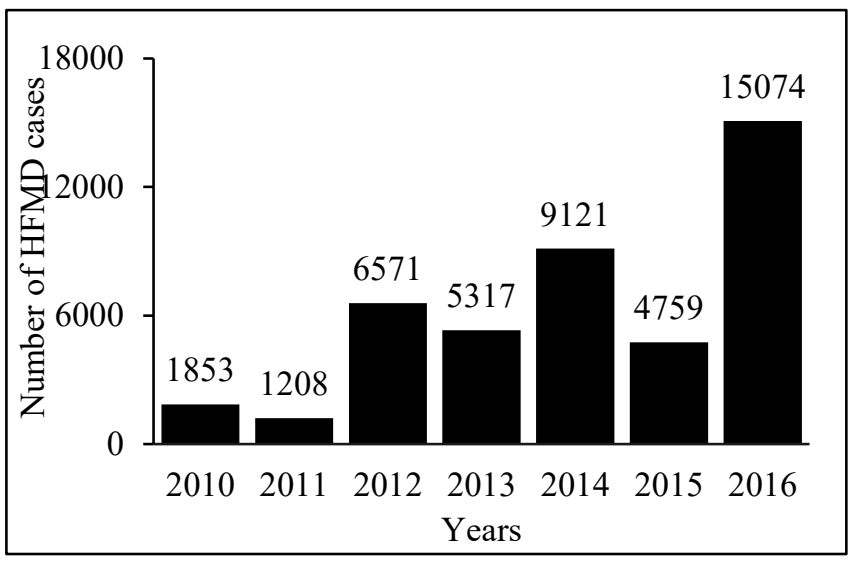

FIGURE 2. Number of HFMD cases in Selangor from 2010 to 2016

SUMMARY STATISTICS FOR HFMD CASES AND

TEMPERATURE IN SELANGOR, MALAYSIA, 2010-2016

The trend on the average number of HFMD disease and the mean temperature per week in Selangor was analyzed as illustrated in Figure 3. It shows that, on average, there was a drastic increase in the number of HFMD cases and temperatures from weeks 1 to 20 and from weeks 1 to 16 , respectively. There was a decreasing temperature at the end of the year which is between weeks 43 and 46 and the HFMD cases show a similar pattern with temperature.

Besides, the weekly summary of HFMD cases in Selangor for seven years of the study period is shown in
Table 1. Based on the information obtained from 43903 cases of HFMD disease from the year of 2010 to 2016, the average number of HFMD cases under study was about 120 cases per week with a standard deviation of 34.4. Nearly 215 cases of HFMD were recorded throughout the year from 2010 to 2016. Also, the mean for temperature in Selangor was $28.3{ }^{\circ} \mathrm{C}$ per week, with a standard deviation of 0.6 . The minimum and maximum mean temperature per week were 27.2 and $29.4{ }^{\circ} \mathrm{C}$, respectively. For maximum and minimum temperature, the range was between 33.5 and $35.6{ }^{\circ} \mathrm{C}$, and between 23.1 and $24.9{ }^{\circ} \mathrm{C}$, respectively.

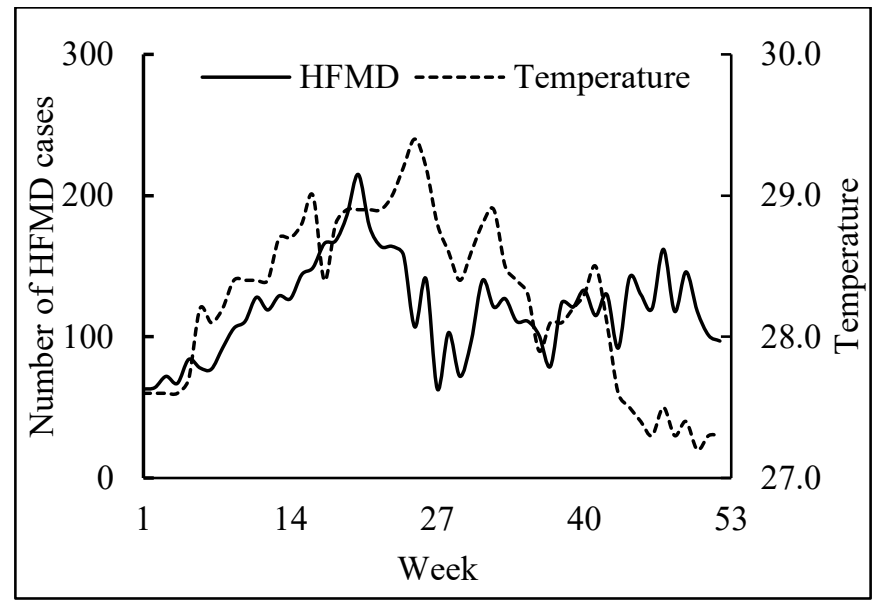

FIGURE 3. Average Number of HFMD cases and temperature per week in Selangor from the year 2010 to 2016 
TABLE 1. Summary of HFMD cases and temperature in Selangor for the year of 2010 to 2016

\begin{tabular}{lccccc}
\hline \multicolumn{1}{c}{ Variables (Unit) } & Mean & $\begin{array}{c}\text { Standard } \\
\text { deviation }\end{array}$ & Minimum & Median & Maximum \\
\hline Weekly total HFMD cases & 119.8 & 34.4 & 63 & 119.5 & 215 \\
Weekly mean temperature $\left({ }^{\circ} \mathrm{C}\right)$ & 28.3 & 0.6 & 27.2 & 28.4 & 29.4 \\
Weekly maximum temperature $\left({ }^{\circ} \mathrm{C}\right)$ & 34.8 & 0.6 & 33.5 & 34.9 & 35.6 \\
Weekly minimum temperature $\left({ }^{\circ} \mathrm{C}\right)$ & 23.9 & 23.1 & 23.1 & 23.9 & 24.9 \\
\hline
\end{tabular}

We found that the percentage of the male gender who were infected by HFMD disease is higher than females by more than half of the cases in this study (Figure 4). There are six ethnic groups used in this study which are Malay, Chinese, Indian, Others (People of Asia descent, and other world nations that are granted citizenship under certain condition, for example, Asian, European and Eurasian), Other Bumiputera (Indigenous native of Sabah and Sarawak, Orang Asli Peninsular Malaysia) and non-Malaysian citizen. In Selangor, Malay ethnic has contributed the largest percentage of HFMD infectious disease with $63.9 \%$ followed by Chinese, Indian, Others ethnicity and Other Bumiputera with 29.9, 4.0, 0.2\% and $1.2 \%$, respectively. However, there was also a nonMalaysian citizen who have been infected by HFMD with $0.8 \%$ equivalent to 116 cases (Figure 5). Based on Figure 6 , the majority of people infected by HFMD disease in Selangor were children aged between 0 and 4 years old with a percentage of $79.3 \%$. Besides, it shows that this infectious disease is also infected in adults over the age of 20 with $1.3 \%$.

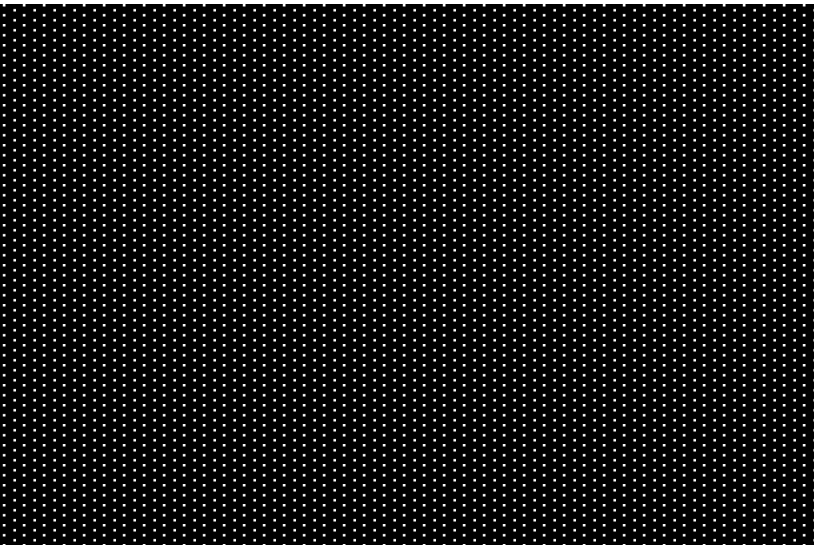

FIGURE 4. Bar chart of HFMD cases based on gender in Selangor

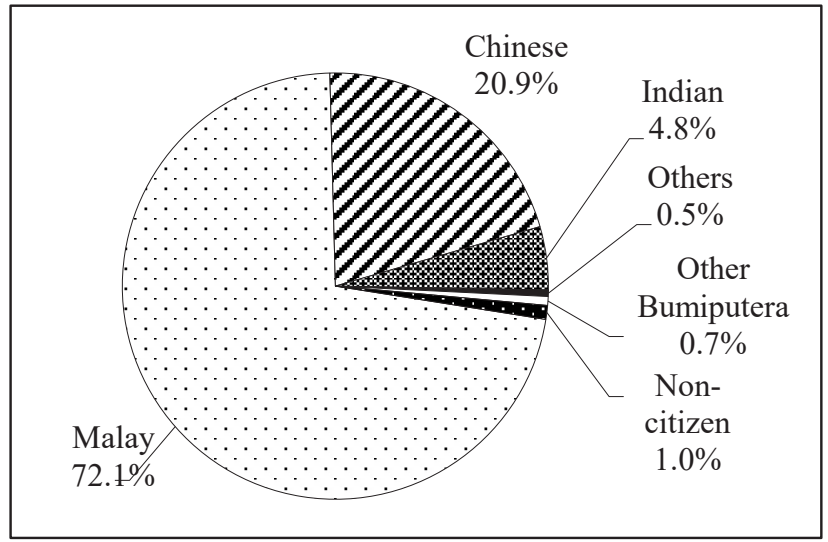

FIGURE 5. Pie chart of HFMD cases based on ethnic in Selangor 


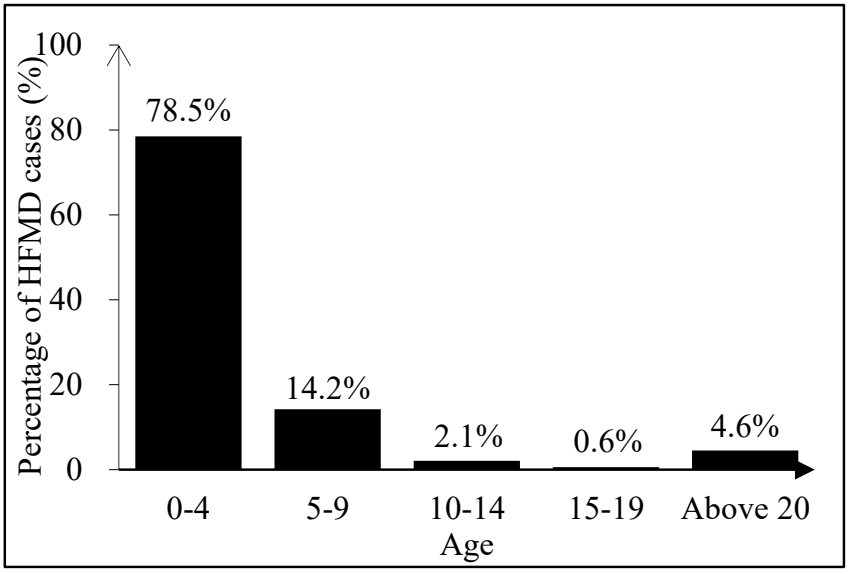

FIGURE 6. Bar chart of HFMD cases based on age in Selangor

\section{MEASURING THE CORRELATION ANALYSIS ON LAG TIME EFFECT}

The results for the Spearman's rank correlation between HFMD cases and temperature with lag time effect is shown in (Table 2). It shows that mean temperature with no lag time, lag of 1 week and lag of 2 weeks are significant and positively associated with HFMD cases with $p$-value $<0.05$. However, temperature with a lag of 3 weeks is insignificant with $p$-value $(0.0928)>0.05$. Therefore, temperature with a lag of 3 weeks will not be selected in the modeling process.

TABLE 2. Spearman's rank correlation between HFMD incidence and temperature with different lag time

\begin{tabular}{lcc}
\hline \multicolumn{1}{l}{ Lag } & Spearman's correlation coefficient, $r$ & $p$-values \\
\hline No lag time & 0.4365 & $\mathbf{0 . 0 0 1 2} * * *$ \\
1 week & 0.3817 & $\mathbf{0 . 0 0 5 7 * * *}$ \\
2 week & 0.2820 & $\mathbf{0 . 0 4 7 2 * * *}$ \\
3 week & 0.2428 & $\mathbf{0 . 0 9 2 8}$ \\
\hline
\end{tabular}

Significant codes: 0.05 '***;

MODELING VIA GENERALIZED LINEAR MODEL WITH POISSON AND NEGATIVE BINOMIAL REGRESSION

The six different models were estimated using two different methods in modeling the HFMD cases which are the Poisson and the negative binomial models (Tables 3
- 5). The models were estimated using 3 different lagged values of explanatory variables, such as no lag time, 1 week, and 2 weeks lag time. Each of the models was assigned as follows: Model A: No lag time, Model B: Lag 1 week, Model C: Lag 2 weeks. 
TABLE 3. Model A: Poisson and Negative Binomial Regression Model with no lag time

\begin{tabular}{|c|c|c|c|c|c|c|}
\hline \multirow[t]{3}{*}{ Model } & \multicolumn{6}{|c|}{$\begin{array}{c}\text { MODEL A } \\
\text { NO LAG TIME }\end{array}$} \\
\hline & \multicolumn{3}{|c|}{ Poisson } & \multicolumn{3}{|c|}{ Negative binomial } \\
\hline & Estimate & $\begin{array}{c}\text { Standard } \\
\text { Error }\end{array}$ & $p$-value & Estimate & $\begin{array}{c}\text { Standard } \\
\text { Error }\end{array}$ & $p$-value \\
\hline Constant & -0.9270 & 0.6124 & 0.130 & -0.6176 & 1.7344 & 0.722 \\
\hline Temperature & 0.2019 & 0.0216 & $0.000 * * *$ & 0.191 & 0.0614 & $0.002 * * *$ \\
\hline Degree of freedom & & 50 & & & 50 & \\
\hline Deviance & & 416.06 & & & 52.69 & \\
\hline Mean deviance & & 8.3212 & & & 1.0538 & \\
\hline AIC & & 762.4 & & & 509.68 & \\
\hline
\end{tabular}

Significant codes: $0.05^{` * * *}$,

TABLE 4. Model B: Poisson and Negative Binomial Regression Model with one week lag time

\begin{tabular}{|c|c|c|c|c|c|c|}
\hline \multirow{3}{*}{ Model } & \multicolumn{6}{|c|}{$\begin{array}{l}\text { MODEL B } \\
\text { LAG } 1 \text { WEEK }\end{array}$} \\
\hline & \multicolumn{3}{|c|}{ Poisson } & \multicolumn{3}{|c|}{ Negative Binomial } \\
\hline & Estimate & $\begin{array}{l}\text { Standard } \\
\text { Error }\end{array}$ & $p$-value & Estimate & $\begin{array}{c}\text { Standard } \\
\text { Error }\end{array}$ & $p$-value \\
\hline Constant & -0.1111 & 0.6246 & 0.859 & 0.0579 & 1.7652 & 0.974 \\
\hline Temperature & 0.1734 & 0.0220 & $0.000 * * *$ & 0.1674 & 0.0624 & $0.007 * * *$ \\
\hline Degree of Freedom & & 49 & & & 49 & \\
\hline Deviance & & 408.72 & & & 51.60 & \\
\hline Mean Deviance & & 8.3412 & & & 1.0531 & \\
\hline AIC & & 749.07 & & & 500.2 & \\
\hline
\end{tabular}

Significant codes: 0.05 '***,

TABLE 5. Model C: Poisson and Negative Binomial Regression Model with two weeks lag time

\begin{tabular}{|c|c|c|c|c|c|c|}
\hline \multirow[t]{3}{*}{ Model } & \multicolumn{6}{|c|}{$\begin{array}{c}\text { MODEL C } \\
\text { LAG } 2 \text { WEEKS }\end{array}$} \\
\hline & \multicolumn{3}{|c|}{ Poisson } & \multicolumn{3}{|c|}{ Negative Binomial } \\
\hline & Estimate & $\begin{array}{c}\text { Standard } \\
\text { Error }\end{array}$ & $p$-value & Estimate & $\begin{array}{c}\text { Standard } \\
\text { Error }\end{array}$ & $p$-value \\
\hline Constant & 1.0147 & 0.6378 & 0.112 & 0.9424 & 1.8027 & 0.601 \\
\hline Temperature & 0.1338 & 0.0225 & $0.000 * * *$ & 0.1364 & 0.1364 & $0.032 * * *$ \\
\hline Degree of Freedom & & 48 & & & 48 & \\
\hline Deviance & & 402.59 & & & 50.50 & \\
\hline Mean Deviance & & 8.3873 & & & 1.0521 & \\
\hline AIC & & 736.94 & & & 490.82 & \\
\hline
\end{tabular}

Significant codes: $0.05^{\prime * * *}$, 
Based on the analysis, we found that the temperature was significant at a $5 \%$ confidence level in all Poisson model. However, the value of mean deviance indicates that there are overdispersion exists. Therefore, the modeling process proceeds with the negative binomial regression for the three models to overcome the overdispersion issues. The mean deviance shows a large amount of reduction in all models after using the negative binomial regression. The negative binomial regression in Model $\mathrm{C}$ gives the best reduction of mean deviance and a smaller value of AIC compared to the other models. This model appears to be an appropriate model for the incidence of HFMD disease using 2 weeks of lagged temperature. After comparing the 6 different models, it can be summarized that the regression equation for the suggested model of HFMD disease in Selangor is best explained by temperature with lag 2 weeks using the Negative Binomial regression model.

Overall, our findings in this study indicate that the temperature with lag 2 weeks have been identified as a significant predictor towards HFMD incidence in Selangor. This result is consistent with the finding of a more recent study in China by Gou et al. (2018) which indicates that the mean temperature is a primary weather factor on HFMD disease. For the lag times effect, they found that 2 weeks lag of overall mean temperature showed the best-predicted model. Another study by Ma et al. (2010) also stated that HFMD trends are better explained if the climatic parameters used are measured 2 weeks before the HFMD clinical consultation rates reported to the health authority. A similar study in Singapore in which they found that the weekly temperature with 2 weeks lags time showed a statistically significant association with HFMD incidence at a time lag of 1 to 2 weeks (Hii et al. 2011). However, the result from this study contradicts to the research that has been done in South Korea in which they stated that, as the temperature increases beyond 18 ${ }^{\circ} \mathrm{C}$, people will begin to feel uncomfortable being outside and will reduce the outdoor activities and therefore, this scenario will decrease the HFMD transmission in those condition (Kim et al. 2016). Thus, the best model to explain the mean HFMD incidence per week form 2010-2016 using lagged of 2 weeks temperature data is as follows:

$$
H F M D_{t}=2.5661\left[e^{0.1364 \text { Temperature }_{t-2}}\right]
$$

This model means that the past 2 weeks of mean temperature value is estimated to positively influence the incidence of HFMD cases by $14.61 \%$.

\section{CONCLUSION}

Since 1997, countries of Asia- Pacific have been affected by large outbreaks of HFMD disease which have resulted in hundreds of thousands of cases and many deaths (Cardosa et al. 1999; Hii et al. 2011; Huang et al. 2013:
Onozuka \& Hashizume 2011; Thanh 2016). This study has focused on how climate variables such as temperature and the effect of time lag can influence the incidence of HFMD in Selangor, Malaysia. Two different analyses have been done; which are regression analysis by using Poisson regression and negative binomial. By applying the Poisson and negative binomial regression analysis, the best model to describe the HFMD incidence was found to be significant when using negative binomial regression with 2 weeks lag time of temperature for HFMD from the year of 2010 to 2016 as the model gave the best reduction of scaled deviance per degree of freedom and smallest value of AIC.

Based on the developed model as shown in (7), we can conclude that weekly mean temperature is an important climatic factor to explain the HFMD incidence in Selangor. Thus, results from this study strongly suggest that climatic parameters such as temperature can be used as early risk indicators for potential HFMD outbreaks. Furthermore, this evidence could provide useful guidance to policymakers or health agencies in terms of giving more consideration to climate variation, especially temperature, to decrease the HFMD cases in Selangor. Therefore, the health authorities in Selangor, Malaysia are advised to give more attention such as speeding up the HFMD prevention control program in the potentially infected area. Similar studies also need to be done in other states and over a longer period to have a better understanding of the impact of temperature on HFMD. Future studies with other climatic variables such as relative humidity, wind speed, and rainfall should also be taken into consideration to strengthen the findings on the impact of the climatic factors towards HFMD.

\section{ACKNOWLEDGEMENTS}

The authors would like to express their greatest appreciation to the Ministry of Health, Malaysia for providing the HFMD data and Malaysian Meteorological Department for providing the climatic data. The work is financed by the Zamalah UTM Scholarship and Research University Grant (QJ130000.2526.17H95) provided by Universiti Teknologi Malaysia and the Ministry of Higher Education, Malaysia.

\section{REFERENCES}

Akaike, H. 1998. Information theory and an extension of the maximum likelihood principle. In Selected Papers of Hirotugu Akaike. New York: Springer. pp. 199-213.

Alsop, J., Flewett, T.H. \& Foster, J.R. 1960. Hand-foot-andmouth disease in Birmingham in 1959. British Medical Journal 2(5214): 1708-1711.

Breslow, N.E. 1984. Extra-Poisson variation in log-linear models. Journal of the Royal Statistical Society: Series $C$ (Applied Statistics) 33(1): 38-44.

Cardosa, M.J., Krishnan, S., Tio, P.H., Perera, D. \& Wong, S.C. 1999. Isolation of subgenus B adenovirus during a fatal 
outbreak of enterovirus 71-associated hand, foot, and mouth disease in Sibu, Sarawak. The Lancet 354(9183): 987-991.

Centers for Disease Control and Prevention 2011. Hand, Foot and Mouth Disease (HFMD). https://www.cdc.gov/hand-footmouth/index.html.

Chan, L.G., Parashar, U.D., Lye, M.S., Ong, F.G.L., Zaki, S.R., Alexander, J.P., Ho, K.K., Han, L.L., Pallansch, M.A., Suleiman, A.B. \& Jegathesan, M. 2000. Deaths of children during an outbreak of hand, foot, and mouth disease in Sarawak, Malaysia: Clinical and pathological characteristics of the disease. Clinical Infectious Diseases 31(3): 678-683.

Chua, K.B. \& Kasri, A.R. 2011. Hand foot and mouth disease due to enterovirus 71 in Malaysia. Virologica Sinica 26(4): 221-228.

Cohen, J.I. 1998. Enterovirus and reovirus. Harrison's Principles of Internal Medicine. New York: McGraw-Hill.

Fairos, W.W.Y., Azaki, W.W.H., Alias, L.M. \& Wah, Y.B. 2010. Modelling dengue fever (DF) and dengue haemorrhagic fever (DHF) outbreak using Poisson and Negative Binomial model. International Journal of Medical, Health, Biomedical, Bioengineering and Pharmaceutical Engineering 4(2): 56-61.

Gou, F., Liu, X., He, J., Liu, D., Cheng, Y., Liu, H., Yang, X., Wei, K., Zheng, Y., Jiang, X. \& Meng, L. 2018. Different responses of weather factors on hand, foot and mouth disease in three different climate areas of Gansu, China. BMC Infectious Diseases 18(15): 1-10.

Hii, Y.L., Rocklöv, J. \& Ng, N. 2011. Short term effects of weather on hand, foot and mouth disease. PloS ONE 6(2): e16796.

Hu, M., Li, Z., Wang, J., Jia, L., Liao, Y., Lai, S., Guo, Y., Zhao, D. \& Yang, W. 2012. Determinants of the incidence of hand, foot and mouth disease in China using geographically weighted regression models. PloS ONE 7(6): e38978.

Huang, Y., Deng, T., Yu, S., Gu, J., Huang, C., Xiao, G. \& Hao, Y. 2013. Effect of meteorological variables on the incidence of hand, foot, and mouth disease in children: A time-series analysis in Guangzhou, China. BMC Infectious Diseases 13(1): 134.

Husam, I.S., Abuhamad, A.A.B., Zainudin, S., Sahani, M. \& Ali, Z.M. 2017. Feature selection algorithms for Malaysian dengue outbreak detection model. Sains Malaysiana 46(2): 255-265.

Kim, B.I., Ki, H., Park, S., Cho, E. \& Chun, B.C. 2016. Effect of climatic factors on hand, foot, and mouth disease in South Korea, 2010-2013. PloS ONE 11(6): e0157500.

Kleinbaum, D.G., Kupper, L.L. \& Muller, K.E. 1988. Applied Regression Analysis and Other Multivariate Methods. Belmot, CA: Duxbury Press.

Koh, W.M., Bogich, T., Siegel, K., Jin, J., Chong, E.Y., Tan, C.Y., Chen, M.I., Horby, P. \& Cook, A.R. 2016. The epidemiology of hand, foot and mouth disease in Asia: A systematic review and analysis. The Pediatric Infectious Disease Journal 35(10): e285-e300.

Lee, C.C.D., Tang, J.H., Hwang, J.S., Shigematsu, M. \& Chan, T.C. 2015. Effect of meteorological and geographical factors on the epidemics of hand, foot, and mouth disease in island-type territory, east Asia. BioMed Research International 2015: 1-8.

Li, T., Yang, Z., Di, B. \& Wang, M. 2014. Hand-foot-andmouth disease and weather factors in Guangzhou, southern China. Epidemiology \& Infection 142(8): 1741-1750.

Ma, E., Lam, T., Wong, C. \& Chuang, S.K. 2010. Is hand, foot and mouth disease associated with meteorological parameter? Epidemiology \& Infection 138(12): 1779-1788.

Melnick, J.L. 1984. Enteroviruses. In Viral Infections of Humans. Boston: Springer. pp. 187-251.

Ministry of Health Malaysia. 2012. Hand, Foot, and Mouth Disease (HFMD): Nasihat Kesihatan (Advisory) HFMD. http://www.moh.gov.my/index.php/pages/view/193.

Onozuka, D. \& Hashizume, M. 2011. The influence of temperature and humidity on the incidence of hand, foot, and mouth disease in Japan. Science of The Total Environment 410-411: 119-125.

Parodi, S. \& Bottarelli, E. 2006. Poisson regression model in epidemiology - An introduction. Annali della Facoltà di Medicina Veterinaria di Parma 26: 25-44.

Pedan, A. 2001. Analysis of count data using the SAS system. In Proceedings of the 26th Annual SAS Users Group International Conference. California. pp. 226-247.

Podin, Y., Gias, E.L., Ong, F., Leong, Y.W., Yee, S.F., Yusof, M.A., Perera, D., Teo, B., Wee, T.Y., Yao, S.C. \& Yao, S.K. 2006. Sentinel surveillance for human enterovirus 71 in Sarawak, Malaysia: Lessons from the first 7 years. BMC Public Health 6(1): 180.

Rasidi, M.N.M., Sahani, M., Othman, H., Hod, R., Idrus, S., Ali, Z.M., Choy, E.A. \& Rosli, M.H. 2013. Aplikasi Sistem Maklumat Geografi untuk pemetaan reruang-masa: Suatu kajian kes denggi di Daerah Seremban, Negeri Sembilan, Malaysia. Sains Malaysiana 42(8): 1073-1080.

Shekhar, K., Lye, M.S., Norlijah, O., Ong, F., Looi, L.M., Khuzaiah, R., Marzuki, I., Hussein, I., Wong, S.L., Mohan, J. \& Sinniah, M. 2005. Deaths in children during an outbreak of hand, foot and mouth disease in Peninsular Malaysia clinical and pathological characteristics. The Medical Journal of Malaysia 60(3): 297-304.

Thanh, T.C. 2016. Effects of climate variations on hand-footmouth disease in Ho Chi Minh city. Vietnam Journal of Science and Technology 54(2A): 120-127.

Van, P.T., Thao, N.T.T., Perera, D., Truong, K.H., Tien, N.T.K., Thuong, T.C., How, O.M., Cardosa, M.J. \& McMinn, P.C. 2007. Epidemiologic and virologic investigation of hand, foot, and mouth disease, southern Vietnam, 2005. Emerging Infectious Diseases 13(11): 1733-1741.

Wang, C., Cao, K., Zhang, Y., Fang, L., Li, X., Xu, Q., Huang, F., Tao, L., Guo, J., Gao, Q. \& Guo, X. 2016. Different effects of meteorological factors on hand, foot and mouth disease in various climates: A spatial panel data model analysis. $B M C$ Infectious Diseases 16(1): 233.

Wood, S.N. 2008. Fast stable direct fitting and smoothness selection for generalized additive models. Journal of the Royal Statistical Society: Series B (Statistical Methodology) 70(3): 495-518 
Xing, W., Liao, Q., Viboud, C., Zhang, J., Sun, J., Wu, J.T., Chang, Z., Liu, F., Fang, V.J., Zheng, Y. \& Cowling, B.J. 2014. Hand, foot, and mouth disease in China, 2008-2012: An epidemiological study. The Lancet Infectious Diseases 14(4): 308-318.

Nurmarni Athirah Abdul Wahid, Jamaludin Suhaila* \& Ayuna Sulekan

Department of Mathematical Sciences

Faculty of Science

Universiti Teknologi Malaysia

81310 Johor Bahru, Johor Darul Takzim

Malaysia
Jamaludin Suhaila*

UTM Centre of Industrial and Applied Mathematics (UTM-CIAM)

Universiti Teknologi Malaysia

81310 Johor Bahru, Johor Darul Takzim

Malaysia

*Corresponding author; email: suhailasj@utm.my

Received: 28 November 2019

Accepted: 16 April 2020 